\section{Godt om søvn}

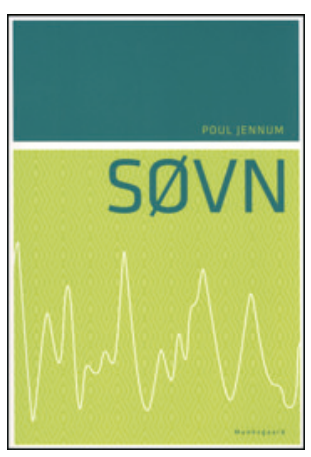

Poul Jennum, red

Søvn

271 s, tab, ill. København: Forlaget

Munksgaard, 2013. Pris DKK 300

ISBN 978-87-628-1053-2
Boken er rettet mot helsepersonell med interesse for søvn, og som diagnostiserer og behandler søvnsykdommer. Redaktør Poul Jennum er overlege ved Dansk Center for Søvnmedicin på Glostrup Hospital og professor i nevrofysiologi ved Københavns Universitet. Søvnmedisin inkluderer mange ulike disipliner, og Jennum har invitert kapittelforfattere knyttet til forskjellige sykehus, spesialiserte sentre og universitetsmiljøer i Danmark og innen forskjellige interesseområder.

Til sammen er det 25 kapitler. Boken fungerer ypperlig som en håndbok om søvn. Kapitlene kan leses uavhengig av hverandre, har passe antall referanser og ender i en oppsummerende faktaboks. Bruken av medisinsk terminologi er beskjeden, og det forutsettes ikke spesiell bakgrunnskunnskap om søvn. Det er flere gode og praktiske tabeller og illustrasjoner. De fleste kapitlene er meget godt oppdaterte, gir praktiske råd om diagnostikk og behandling og er fornøyelige å lese.

Bidragsyterne begynner med en beskrivelse av normal søvn, metoder for bestemmelse av søvn og våkenhet og hjernens regulering av søvn. Døgnrytmeforstyrrelser beskriver de lett i kapitlet om biologien ved døgnrytmer, men det burde fått et eget kapittel. Kunnskap om og behandling av døgnrytmeforstyrrelser med lys og/eller melatonin er etterspurt av helsepersonell. Spesielt viktig er kunnskap om pasientens egen døgnrytme før start av behandling, noe som mangler. Hovedkategoriene av søvnsykdommer beskrives ellers godt.

Boken har en del skrivefeil og små mangler. En noe mer nøyaktig presisering og bruk av referanser kunne gjort den mer komplett. For eksempel mangler bruk av pulsoksymetri som supplerende polygrafisk mål til søvnregistrering. Kliniske verktøyer som ofte brukes, kunne vært grundigere gjennomgått og viet et eget kapittel. Eksempler er søvndagbok og instruksjon for bruk av denne, og hvilken informasjon rapporten etter en søvnregistrering vil gi. Råd om klinisk informasjon om søvnighet burde også inneholde informasjon om høneblunder (antall og varighet), om pasienten har samme søvnmønster i helgene, bruk av sovemedisin og koffeinholdige drikker.

Disse innvendingene til tross, dette er en bok som mange vil ha nytte av. Søvn er biologisk helt nødvendig. Mangel på søvn eller søvnforstyrrelser fører til svekket dagtidsfunksjon, mentale og fysiske endringer. Søvnmedisin er et ungt fagfelt, og mange ulike disipliner er involvert i håndteringen av pasientene. Området er $i$ betydelig utvikling. Forfatterne har med denne utgivelsen lyktes i å spre oppdatert kunnskap og forståelse av hvor viktig det er med god søvn for god helse.

\section{Slankere bokversjon - komplett på nett}

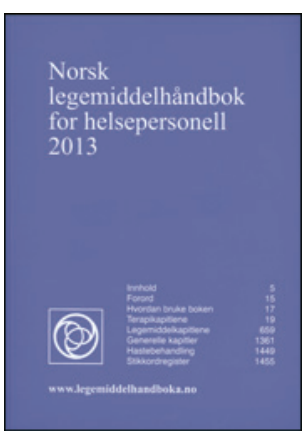

\author{
Trygve Fjeldstad, red. \\ Norsk legemiddelhåndbok \\ for helsepersonell 2013
}

$1502 \mathrm{~s}, \mathrm{tab}, \mathrm{ill}$. Oslo: Foreningen for utgivelse av Norsk legemiddelhåndbok, 2013. Pris NOK 395

ISBN 978-82-90732-11-5

Norsk legemiddelhåndbok for helsepersonell er en velkjent og autoritativ oppslagsbok som distribueres fritt til leger, farmasøyter, studenter, sykehus og helseinstitusjoner. Publikasjonen er finansiert av staten, og det redaksjonelle arbeidet er tuftet på et samarbeid mellom Apotekforeningen, Helsedirektoratet, Legeforeningen, Nasjonalt kunnskapssenter for helsetjenesten og Statens legemiddelverk

Den trykte 2013-versjonen er redusert med 500 sider siden forrige revisjon i 2010. Dette har vært et nødvendig grep, da de foregående bøkene suksessivt este ut til uhåndterlige dimensjoner - et paradoks til en «håndbok» å være. Færre sider betyr ikke at viktig stoff er utelatt. Man har bare valgt å flytte en rekke kapitler fra bok til internett - hvilket er fornuftig å gjøre i en tid med ekspanderende legemiddelinformasjon.

Boken er beregnet på medisinske generalister som allmennleger, sykehjemsleger og turnusleger. I de 24 terapikapitlene (T-kapitlene) omtaler man viktige sykdommer og grunnlaget for behandlingsstrategier. Deretter følger 21 legemiddelkapitler (L-kapitler) hvor man utdyper indikasjoner og bruksområder for legemidler. Den siste delen består av 24 generelle kapitler (G1-G24) som omhandler medisinsk farmakologi og forskrivningspraksis.

Papirversjonen inkluderer de fleste terapi- og legemiddelkapitlene og enkelte generelle kapitler med særlig relevans for forskrivning, så som kapitlene om legemiddelbruk ved nedsatt nyre- og leverfunksjon. En rekke tabeller finnes nå bare i nettversjonen, mens interaksjonstabellen er strøket fra både nett og papir. I stedet henvises det til Legemiddelverkets interaksjonssøk. Behandlingsveilederne START, STOP og NorGeP er lagt til kapitlet om eldre og legemidler, og systematisk legemiddelgjennomgang er tatt inn som eget kapittel.

Nettversjonen har stilren design, oversiktlig tematikk og klikkbare kryssreferanser. Søkefunksjonen er blitt mer nyansert, med bedre vekting av treff. Personlig synes jeg nettversjonen fungerer best på nettbrett: Søk på «hypertensjon», og du vil få opp instruktive artikler som du kan sveipe gjennom i ro og mak. Applikasjonen for smarttelefoner er en god nyhet, men her bør søkefunksjonen bli mer målrettet. At teksten ikke lar seg ekspandere på «touch screen» er også et lite skår i lesegleden.

Til tross for disse få innvendingene av teknisk art, synes jeg at integreringen mellom papir og nett er spennende og vellykket for legemiddelhåndboken. Jeg vil anbefale kolleger å laste opp nettversjonen som en favoritt på nettleseren - og bruke den som et skattkammer for faglig fordypning. Samtidig fortjener papirversjonen fortsatt en sentral plass i bokreolen.

Tom Sundar

Kommunelege, Rendalen legekontor 